\title{
AN EMPIRICAL STUDY OF PROFESSIONAL EXHAUSTION AND LIFE POSITION OF EDUCATIONAL PRINCIPLE STAFF AND DIRECTORSHIP
}

\section{Tavrovetska N.}

\section{INTRODUCTION}

The phenomenon "professional exhaustion" is known for a long time, since the beginning of the century, it has become a symbol of the industrial era. In the 70s, this phenomenon was sharply defined as burnout due to the autobiographical publications of $\mathrm{H}$. Freudenberger on the demotivation of volunteers working in a drug treatment clinic ${ }^{1}$. Soon, active research began, on the basis of which explanatory theories were created (C. Maslach \& S. Jackson, 1981²; M. Burish, 1989², W. Schaufeli, $1990^{4}$ ), which are still acknowledged today. The very first publications caused a widespread public resonance, which contributed to the recognition and dissemination of this term in academic discourse. In general, burnout is defined as a profound professional and personality crisis: "a state of exhaustion in which one is cynical about the value of one's occupation and doubtful of one's capacity to perform",

Today in America, specialized magazines devoted to the problem of burnout have been created, scientific congresses are held, largescale researches and social programs have been initiated. Burnout has gained official status in Sweden and the Netherlands; in 2018, it turned out to be the most frequent reason for being absent at work (more than

${ }^{1}$ Freudenberger H. Staff Burnout. Journal of Social Issues. 1974. Vol. 30. P. 159-165.

2 Maslach C., Jackson S. E. The measurement of experienced burnout. Journal of Occupational Behaviour. 1981. Vol. 2. P. 99-113.

3 Burish M. Das Burnout-Syndrom: Theorie der inneren Erschöpfung. Berlin, Heidelberg: Springer-Verlag, 2014. 292 p.

${ }^{4}$ Schaufeli W. B. Opgebrand : over de achtergronden van werkstress : het burnoutsyndroom. Rotterdam: Donker. 1990. 224 p.

${ }^{5}$ Maslach C., Jackson S.E., Leiter M.P. Maslach burnout inventory. Manual (3rd ed.). Palo Alto, Calif. : Consulting Psychologists Press, 1996. 34 p. 
$20 \%$ of sickness certificates in all age categories) ${ }^{6}$. As an official diagnosis, burnout makes it possible to receive psychotherapeutic counseling, treatment and rehabilitation, and financial compensation. It also means that the syndrome is included in reference books and textbooks; that medical personnel can diagnose and treat burnout; that there is professional practice - psychologists, organizational consultants, social workers offer a wide range of assistance and prevention programs ${ }^{7}$.

Other European countries (including Ukraine) are guided by the recommendations of the WHO, which defines burnout not as a disease, but as an occupational phenomenon (ICD-10 Diagnosis Code Z73.0). In the revised edition of ICD-11, the description of this syndrome is significantly expanded, it is recognized as the result of chronic stress at the workplace, which has not been successfully overcome, and includes three main signs: a) a feeling of motivational and physical exhaustion; b) negativism and cynicism, distancing oneself from professional duties; c) reduced productivity ${ }^{8}$.

Over the past 50 years, many studies have been conducted confirming the seriousness of the problem. The prevalence of burnout in various cultures all over the world, in different social and age groups is shown. The changes in the structure and functioning of the brain, accompanying the burnout process are detected ${ }^{9}$. This is accompanied by violations of the endocrine system: insufficient production of morning cortisol is an objective reason for daily apathy and vulnerability to stress ${ }^{10}$.

The generally recognized reason of burnout is the imbalance of external requirements and the internal resource of vital activity (physiological, energetic, emotional, motivational, etc.). A person

${ }^{6}$ Burnout is rising in the land of work-life balance [Video by M. Savage and B. Derrier]. BBC Worklife.

${ }^{7}$ Schaufeli W. B., Leiter M., Maslach C. Burnout: 35 Years of research and practice. Career Development International. 2009. Vol. 14, № 3. Р. 204-220.

8 Всемирная организация здравоохранения. Международная классификация болезней: «профессиональный синдром» эмоционального выгорания. URL: https://www.who.int/mental_health/evidence/burn-out/ru/ (дата звернення: 26.09.2019)

${ }^{9}$ Savic I. Structural Changes of the Brain in Relation to Occupational Stress. Cerebral Cortex. 2015. Vol. 25, Is. 6. P. 1554-1564.

${ }^{10}$ Oosterholt B. G., Maes J. H., Van der Linden D., Verbraak M. J., Kompier M. A. Burnout and cortisol: Evidence for a lower cortisol awakening response in both clinical and nonclinical burnout. Journal of Psychosomatic Research. 2015. Vol. 78, Is. 5, P. 445-451. 
contributes more to work than receives in return ${ }^{11}$. The opinion that the danger of burnout goes beyond the scope of human services professions, and even beyond the scope of any professional activity (for example, «partner» or «parental» burnout) is becoming increasingly widespread ${ }^{12}$.

L. D. Demina and I. A. Ralnikova consider this syndrome as an integrative psychological defense - a functional stereotype that saves energy resources and maintains mental health in a situation of maladaptation $^{13}$. But, according to the studies of L. A. Kitaev-Smyk, burnout is much more than ordinary fatigue or a reaction to stress - it is a crisis affecting the highest levels of psychological regulation: values and meanings of life $^{14}$. Burnout experience destroys professional and personal identity. R. Gunderman subtly described this process as the accumulation of disappointments «It is the sum total of hundreds and thousands of tiny betrayals of purpose, each one so minute that it hardly attracts notice ${ }^{15}$. Following social criteria of success, organizational rules and other people's values, many specialists deviate surprisingly far from their original life goal.

The post-industrial era, with its inherent priority of self-realization and personal responsibility of a individual for their life and career, complicated the mechanisms of burnout development. This actualizes the study of the value-semantic aspects of life activity associated with occupational stress and its overcoming. The purpose of this study is to elucidate the relationship between expressiveness of professional burnout and the characteristics of value-semantic orientations. This is a complex and important issue, which is based on a contradiction: on the one hand, an active and responsible life position is resourceconsuming, i.e. contributes to burnout, on the other hand, finding the meaning and value of one's own activity is a condition for lasting and successful existence in the profession.

${ }^{11}$ Bakker A. B., Demerouti E. Job demands-resources theory: Taking stock and looking forward. Journal of occupational health psychology. 2017. Vol. 22, № 3. P. 273-285.

12 Hubert S., Aujoulat I. Parental Burnout: When Exhausted Mothers Open Up. Frontiers in Psychology. 2018. Vol. 9. Р. 1021.

13 Демина Л. Д., Ральникова И. А. Психологическое здоровье и защитные механизмы личности. Барнаул: Изд-во АлтГУ, 2005. 132 с.

${ }^{14}$ Китаев-Смык Л. А. Организм и стресс. Стресс жизни и стресс смерти. Москва : Смысл, 2012. 464 с.

${ }^{15}$ Gunderman R. For the young doctor about to burn out. The Atlantic. 2014, February 21. 


\section{The overview of professional burnout of educational principle staff}

The education sector traditionally occupies a leading position in the list of occupations subjected to risk of professional burnout. This is caused by the large amount of workload, the need for constant communication with students and parents, taking into account their individual characteristics and problems, the emotional intenseness of the work (the accumulation of negative emotions without the possibility of their direct «discharge»), a high level of organizational control. In the Ukrainian educational sector, the situation is complicated by constant and unsuccessful reforms (changes in the rules and standards of work), low pay and the lack of social prestige of the teaching profession.

We conducted a study of teachers of Kherson secondary and specialized schools. The survey was held in the first academic semester (November-December 2018) as part of regular psycho-preventive, vocational guidance and psycho-hygienic activities. Participants were familiarized with the purpose of the study in advance and agreed to use their data for scientific purposes. The sample consisted of 86 people, including: 20 school principals (heads of school and directors of teaching): 14 women and 6 men, 66 employees (teachers, educators, psychologists, social workers) of secondary and high schools; mainly women $(75.7 \%)$, which reflects the demographic characteristics of this profession. The age of test subjects ranged from 26 to 58 years old (average age was 33.8), the experience of pedagogical work ranged from 5 to 36 years.

To diagnose burnout symptoms, a standardized questionnaire "Professional burnout" was used for specialists in socionomic professions, developed in 2003 by N. E. Vodopianova and E. S. Starchenkova ${ }^{16}$. The methodology is based on the universally recognized three-factor model of Maslach \& Jackson, which considers burnout as a dynamic process distributed over time into separate phases:

${ }^{16}$ Водопьянова Н. Е., Старченкова Е. С., Наследов А. Д. Стандартизированный опросник «Профессиональное выгорание» для специалистов социономических профессий. Вестник Санкт-Петербургского университета. Серия 12. Социология. 2013. Вып. 4. С. 17-27. 
1) Emotional exhaustion is a consequence of emotional overstrain (excessive involvement in work) and is manifested in a feeling of tiredness, emptiness, exhaustion of one's own resources. There is a feeling of «muffledness», «dullness», in severe manifestations emotional breakdowns are possible.

2) Depersonalization is a loss of high ideals, feelings of cynicism and detachment from the job (also described as negative, critical, soulless attitude to other subjects of professional activity). In the process of burnout, contacts become formal, impersonal, and conflicts arise.

3) The reduction of personal accomplishments is manifested in disappointment from the lack of expected fair remuneration for work, in decrease of professional motivation. It's possible to have feeling of inadequacy, incompetence, dissatisfaction with themselves and others, negative self-esteem of results (as a result, there is a real decrease in productivity and work efficiency, a person is simply not able to do what they did before). Due to the development of burnout processes alienation to work and life in general and psychosomatic health disorders are emerging.

Thus, the questionnaire contains three symptomatic scales characterizing the phase dynamics of burnout. The existence of irregularities is indicated by high scores on the subscales of emotional exhaustion and depersonalization, by low scores on the Professional accomplishment scale (reduction of personal achievements). The scores obtained were converted into integral index with a special formula, bringing it into conformity with the Stan scale (average value of the integral indicator is 5.5, standard deviation is 2) (Vodopianova, pp. 24-25).

The data obtained were processed using descriptive statistics (calculation of average trends and scatter measures, frequency analysis) of correlation analysis. Diagnosis of symptoms of professional burnout among educational principal staff and directorship gave unexpected, at first glance, results. 
Table 1

Comparative analysis of the expressiveness of burnout symptoms $(M \pm S D)$ among educational principal staff and directorship

\begin{tabular}{|c|c|c|c|c|}
\hline & $\begin{array}{c}\text { Integral } \\
\text { index }\end{array}$ & $\begin{array}{c}\text { Emotional } \\
\text { exhaustion }\end{array}$ & $\begin{array}{c}\text { Depersonali } \\
\text { zation }\end{array}$ & $\begin{array}{c}\text { Professional } \\
\text { accomplishment }\end{array}$ \\
\hline $\begin{array}{c}\text { educational } \\
\text { principal staff }\end{array}$ & $4,75 \pm 2,19$ & $19,51 \pm 7,96$ & $8,45 \pm 5,36$ & $33,70 \pm 7,57$ \\
\hline directorship & $5,31 \pm 1,31$ & $20,23 \pm 7,65$ & $12,50 \pm 4,62$ & $36,25 \pm 6,68$ \\
\hline $\begin{array}{c}\text { relevance of } \\
\text { differences, U* }\end{array}$ & 0,22 & 0,69 & 0,01 & 0,34 \\
\hline
\end{tabular}

Note. ${ }^{*}$ the significance of the Mann-Whitney U-test is indicated, with a value of $\leq 0.05$ a hypothesis on the significance of differences between groups is accepted

Table 1 shows that although the average indicators of burnout symptoms among management are slightly higher than among employees, in general, the difference in the integral indicator does not have statistical significance. There is no doubt that the level of professional stress of management is higher than that of ordinary employees. Their activities are accompanied by constant mental stress, participation in resolving conflict situations, the need for making managerial decisions, responsibility for the results of the work of the entire school, high requirements for professional and personal qualities, irregular working hours, etc. However, at the same time, directors have greater remuneration for work (in the form of social and material resources), which helps to maintain the necessary adaptive balance. Awareness of personal accomplishments helps management to neutralize emotional exhaustion. Thus, the results obtained do not prove that management in the system of education has higher level of burnout risk than ordinary employees in the same field.

In general, the prevalence of burnout syndrome in the sample is relatively small - no more than $18 \%$ among ordinary educational principal staff and 15\% among directorship (Fig. 1). Moreover, among the educational principal staff, the number of respondents with a low level of burnout exceeds the number of «burned out» (in general, the distribution is close to normal). The distribution of data in the group of directorship differs from normal one, as well as from expected based on the process-dynamic theory of burnout. All members of directorship demonstrate a high or medium level of professional accomplishment this fact is intelligible, since they have obvious career progress and achievements. In addition, the school directorship has higher indicator of the Depersonalization scale (when compared with principal staff, 
the difference is significant at $\mathrm{p}=0.01$ ). Not a single director received low evaluation score; but the excess of standard indicators was identified in $40 \%$ of test subjects. In all these cases, high depersonalization is combined with emotional involvement in work (low expressiveness of the symptom of exhaustion). Correlation analysis showed that, unlike ordinary principle staff, the indicator of directorship's depersonalization of is not associated with other scales and an integral burnout index (Fig. 2).

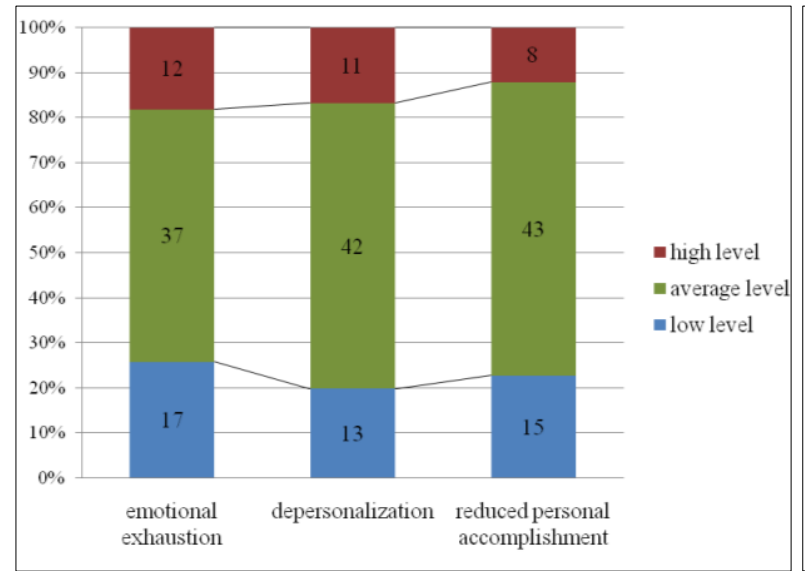

A) educational principal staff ( $\mathrm{N}=66)$

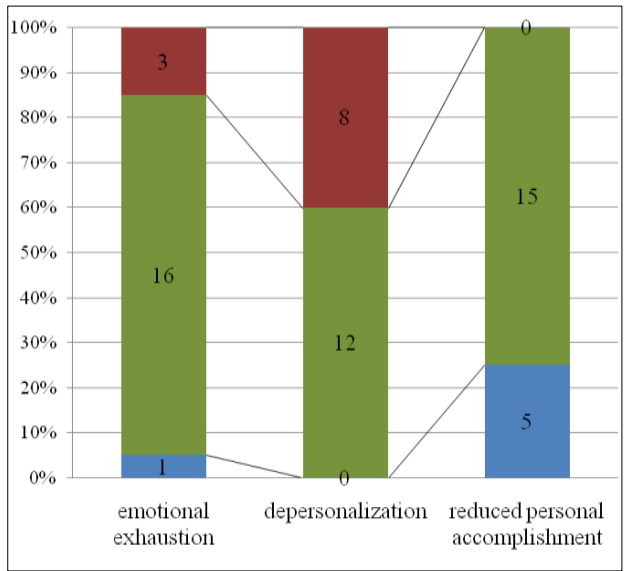

B) directorship $(\mathrm{N}=20)$

\section{Fig. 1. Distribution of professional burnout indicators among educational principal staff (A) and directorship (B) (number of observations and \% share)}

Most likely, the depersonalization of directorship is not a symptom or a consequence of burnout at work. This is a component of other personality disorders or professional destructions, which is typical for managers. In the sample of directorship, the expressiveness of depersonalization is directly related to the self-assessment of professional accomplishment (although the correlation does not reach a statistically significant level). This contradicts the logic of the development of the burnout process in accordance with the Maslach \& Jackson model. This correlation can be explained by the fact that effective managers are annoyed with slow and incompetent employees, they do not allow themselves to show emotions in relationships with colleagues (impartiality is associated with insensibility), they use subordinates as a tool for achieving their organizational goals. Interestingly, at the level of separate points, the depersonalization 
indicator correlates with the ability to put a "spark" to the work and motivate subordinates $(\mathrm{p} \leq 0.05)$, with the ability to create an atmosphere of benevolence and cooperation in the team $(\mathrm{p} \leq 0.05)$.

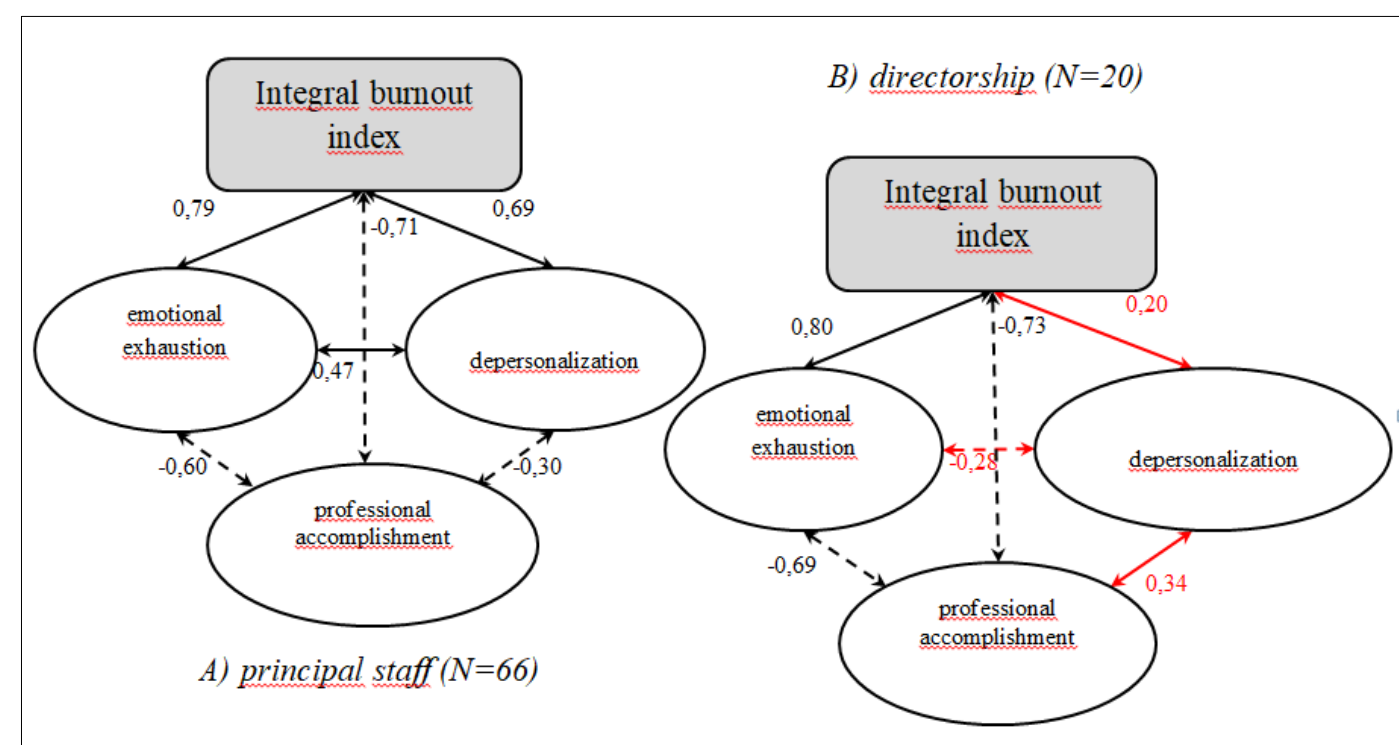

\section{Fig. 2. Structural correlation of burnout indices in the samples of educational principle staff and directorship (the connections highlighted in red are insignificant for a given sample)}

All this indicates that the mechanism of burnout development and the structure of its individual components have professional specifics. Earlier, N. E. Vodopianova, E. S. Starchenkova, and A. D. Nasledov pointed out that a certain level of depersonalization is a necessary mechanism for psychological defense and adaptation for a number of communicative professions. The results obtained expand these ideas; they should be taken into account in the psychological diagnosis of various categories of management.

In addition, there are theoretical concepts and empirical studies that explain the stages of burnout development differently than the generally accepted three-factor model of Maslach \& Jackson. For example, R. Golembiewski \& R. Munzenrider (1988) confirm that cynicism is an early (minimal) phase of burnout, followed by a decrease in efficiency and, finally, exhaustion ${ }^{17}$. Recent studies of M.P. Leiter, C. Maslach (2016) revealed five latent burnout profiles:

${ }^{17}$ Golembiewski R. T., Munzenrider R. Phases of burnout: Developments inconcepts and applications. New York: Praeger. 1988. 292 p. 
Burnout (high on all three dimensions), Engagement (low on all three dimensions), Overextended (high exhaustion), Disengaged (high cynicism), and Ineffective (high inefficacy) ${ }^{18}$. This gives a new idea on the variety of burnout manifestations.

In the results of correlation analysis, a negative correlation between the indicator of professional accomplishment and professional experience is noteworthy (this tendency is typical for all categories of employees of educational institutions). That is, not only natural emotional exhaustion happens with age, but also the depreciation of one's professional activity. More careful examination of correlations at the level of separate points of the questionnaire showed that with the accumulation of professional experience (this indicator, in turn, is closely connected with age), an assessment of the efforts made to work is significantly reduced, as well as the ability to avoid conflicts; the ability to motivate, "spark" partners and subordinates; the ability to create a friendly atmosphere of cooperation, and an assessment of one's own life prospects and opportunities - see table. 2.

With regard to interpretation of the indicators of the "Professional accomplishment" scale, N. E. Vodopianova and co-authors note the influence of age and the stage of personal development in the profession: the period of professional adaptation is associated with the awareness of young specialists of a certain insufficiency of their knowledge and skills, i.e. low scores of young educators on the scale are not a symptom of burnout. For mature employees at maturity and late maturity stages, low scores on the scale indicate a reduced self-esteem of the results achieved and a secondary decrease in productivity due to the change in attitude to work. Our results confirm these observations.

When comparing the general picture of burnout of educators with the data of previous studies, we found that our statistics are more optimistic. Thus, in a study of E.I. Bondarchuk (2008), a high level of burnout was recorded in $28 \%$ of the leaders of educational institutions ${ }^{19}$. It should be noted that the statistics on professional burnout are strongly influenced by the time of the study: the educator's work has a strongly marked annual cycle with a peak of fatigue in April-June and the subsequent recovery period.

${ }^{18}$ Leitera M. P., Maslach C. Latent burnout profiles: A new approach to understanding theburnout experience. Burnout Research. 2016. Vol. 3. P. 89-100.

19 Бондарчук О. I. Соціально-психологічні основи особистісного розвитку керівників загальноосвітніх навчальних закладів у професійній діяльності : автореф. дис. ... д-ра психол. наук : 19.00.05. Київ, 2008. 34 с. 
Table 2

\section{Correlations of individual manifestations of the reduction of professional accomplishments in the general sample of educators $(N=86)$}

\begin{tabular}{|c|c|c|c|c|c|}
\hline $\begin{array}{c}\text { Scale points } \\
\text { «Professional } \\
\text { accomplishment» }\end{array}$ & 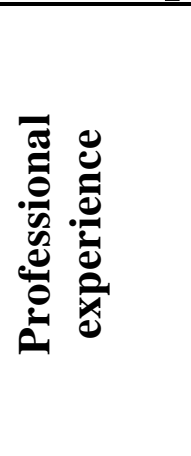 & 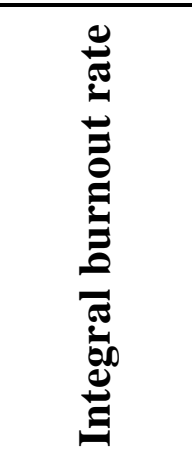 & 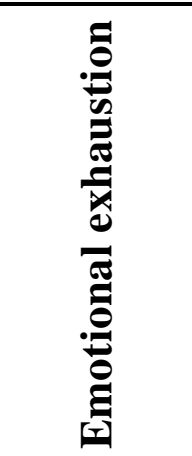 & 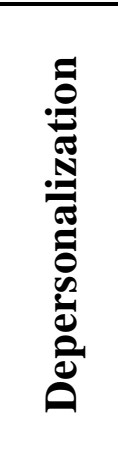 & 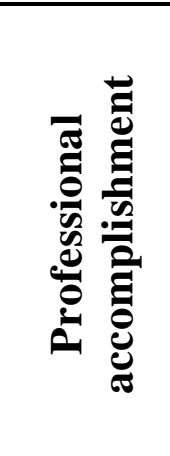 \\
\hline $\begin{array}{l}\text { 4. The results of my work } \\
\text { are not worth the efforts } \\
\text { I expend }\end{array}$ & $-0,32 * *$ & $-0,43 * * *$ & $-0,18$ & 0,04 & $0,51 * * *$ \\
\hline $\begin{array}{l}\text { 7. When talking to } \\
\text { aggressive or conflict } \\
\text { employees, I can negotiate } \\
\text { and avoid conflicts }\end{array}$ & $-0,23 *$ & $-0,16$ & $-0,35 * *$ & 0,18 & $0,36 * *$ \\
\hline $\begin{array}{l}\text { 9. I can put a "spark" in } \\
\text { the work (spark interest) } \\
\text { of my subordinates } \\
\text { (business partners) }\end{array}$ & $-0,43 * * *$ & $-0,17$ & $-0,22 *$ & $0,24 *$ & $0,60 * * *$ \\
\hline $\begin{array}{l}\text { 12. I work with pleasure, } \\
\text { I have many plans for the } \\
\text { future related to my } \\
\text { professional development. } \\
\text { I believe in their } \\
\text { implementation }\end{array}$ & $-0,14$ & $-0,46 * * *$ & $-0,51 * * *$ & 0,07 & $0,58 * * *$ \\
\hline $\begin{array}{l}\text { 17. I can easily create an } \\
\text { atmosphere of friendliness } \\
\text { and cooperation in the } \\
\text { team }\end{array}$ & $-0,25^{*}$ & 0,13 & 0,00 & 0,21 & 0,12 \\
\hline $\begin{array}{l}\text { 18. I easily communicate } \\
\text { at work with everyone } \\
\text { regardless of their } \\
\text { ambitions, emotional state } \\
\text { and manner of } \\
\text { communication }\end{array}$ & 0,05 & 0,05 & 0,06 & 0,13 & 0,13 \\
\hline $\begin{array}{l}\text { 19. I am satisfied with my } \\
\text { life and professional } \\
\text { progress } \\
\text { (accomplishments) }\end{array}$ & $-0,15$ & $-0,26^{*}$ & $-0,12$ & $-0,15$ & $0,22 *$ \\
\hline $\begin{array}{l}\text { 21. I can still do a lot in } \\
\text { my life }\end{array}$ & $-0,26^{*}$ & $-0,36 * *$ & $-0,45 * * *$ & 0,14 & $0,67 * * *$ \\
\hline
\end{tabular}

Note. ${ }^{*} \mathrm{p} \leq 0,05, * * \mathrm{p} \leq 0,01, * * * \mathrm{p} \leq 0,001$ 


\section{The relationship of professional burnout with the characteristics of value-semantic sphere and life position of educators}

For diagnosing life position and value orientations of educational principle staff a set of questionnaires was used:

- The questionnaire of life orientations of E. Yu. Korzhova allows us to conclude about the features of life self-determination. The scales of the technique reflect the basic components of life orientations: variability - stability (the desire to change or stay the same); internal external locus of control (acceptance or delegation of responsibility); focus on the development of the internal - external world (the desire for self-improvement or for practical activities); mobility - inertness (desire for something new or habitual). High scores on the scales reflect the subject orientation characteristic of a person with an active life position and internal determination of vital activity; low scores reflect the object orientation characteristic of a person with a passive life position, determination of the way of life mainly by external life circumstances ${ }^{20}$.

- Schwartz's methodology for studying personality values is developed on the basis of the author's theoretical model explaining values as universal motivational types that are present in all cultures and social layers. The methodology gives an assessment of 10 scales representing vital, basic values (the needs of an individual, society, human species as a whole): Power, Achievement, Hedonism, Stimulation, Self-Direction, Universalism, Benevolence, Tradition, Conformity, Security. Two parts of the methodology examine the same values in different aspects: 1) as declared ideals, norms and beliefs that define a personality, but not always manifested in behavior, and 2) as principal trends in social behavior ${ }^{21}$. Schwartz Value Survey includes 60 terminal and instrumental value orientations, which are scored by the respondent from 7 (value of highest importance) to -1 (value opposite to their own beliefs). We analyzed the scores for each item to identify the predominance of individual value ideals in the structure of professional burnout.

${ }^{20}$ Коржова Е.Ю. Психология жизненных ориентаций человека. Санкт-Петербург : Изд-во РХГА, 2006. 384 с.

21 Карандашев В. Н. Методика Шварца для изучения ценностей личности: концепция и методическое руководство. Санкт-Петербург : Речь, 2004. 72 с. 
- The scale of existence of A. Langle, K. Orgler (Langle-Orgler Existence Scale, 1989) presents an existential-analytical approach and is intended to assess the quality of human life from the point of view of its meaningfulness and fullness. The general indicator of the questionnaire - existential fulfillment proves the ability to "deal with oneself and the world and be able to accept internal and external requirements and proposals, correlating them with one's own values" $^{22}$. It consists of 4 scales - anthropological abilities reflecting the steps towards finding meaning in life: a person should first perceive life soberly and realistically, see the field of his/her opportunities (self-distance); then "skip" these opportunities through himself/herself, correlate them with his/her own values and be emotionally affected by them (self-transcendence); choose the best situation and the best opportunity for himself/herself and make a decision in its favor (freedom); to consider the methods of action in accordance with the decision made and implement it, thereby introducing the discovered meaning into life (responsibility).

- Maddi's test of subjective alienation (adaptation of E. N. Osin, 2007) was used to measure an individual's experience of existential neurosis and meaninglessness in various areas of life: alienation from work, from society, alienation in interpersonal relationships, from family and alienation from oneself $\mathrm{f}^{23}$.

- Maddi's hardiness test in adaptation of D. O. Leontev and O. I. Rasskazova (2006). Hardiness is "the courage to be", it is a system of beliefs about the self, the world, attitude towards it, which allow a person to withstand and effectively overcome stressful situations. It includes three independent components: commitment determines the pleasure of one's own activity, which implies a conviction in the generosity of the world and self-confidence; control represents the choice of one's way, the belief that one's own efforts can influence the outcome of what is happening, even if success is not guaranteed (the opposite is the feeling of helplessness); challenge - the individual's conviction that everything good or bad that happens to

${ }^{22}$ Кривцова С. В., Лэнгле А., Орглер К. Шкала экзистенции (Existenzskala) А. Лэнгле и К. Орглер. Экзистенциальный анализ. 2009. №1. Бюллетень. С. 141-170.

23 Осин Е. Н. Смыслоутрата как переживание отчуждения: структура и диагностика : дис. ... канд. психол. наук : 19.00.01. Москва. 2007. 217 с. 
him/her contributes to his/her development through knowledge and experience $^{24}$.

- The coping test of R. Lazarus and S. Folkman allows exploring the ways of overcoming difficulties in various areas of mental activity. It includes the following coping strategies: confrontation, distancing from a problem, self-control of emotions and behavior, the search for social support, acceptance of responsibility, planning a solution to a problem, escape-avoidance, positive re-evaluation ${ }^{25}$.

The data obtained were processed using correlation and factor analysis (Microsoft Excel 2010 and SPSS 18.0).

Correlation analysis revealed a number of significant interactions between burnout and the highest personal dispositions. Table 2.3 shows significant correlations (we focused on a critical indicator of the Pearson correlation coefficient for the sample of 80 people: 0.815 for $\mathrm{p} \leq 0.10 ; 0.220$ for $\mathrm{p} \leq 0.05 ; 0.286$ for $\mathrm{p} \leq 0.01,0.361$ for $\mathrm{p} \leq 0.001$ )

Table 3

Significant correlations of professional burnout indicators with the results of personality questionnaires

\begin{tabular}{|c|c|c|c|c|}
\hline & 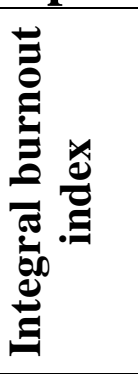 & 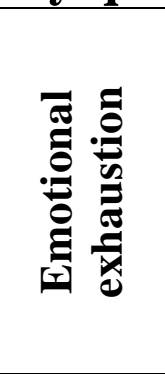 & 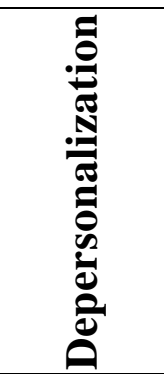 & 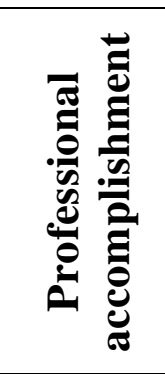 \\
\hline 1 & 2 & 3 & 4 & 5 \\
\hline Age & - & $0,38 * * *$ & $0,29 * *$ & $-0,28 * *$ \\
\hline Professional experience & - & $0,28 * *$ & $0,23^{*}$ & $-0,25^{*}$ \\
\hline \multicolumn{5}{|c|}{ List of value orientations of Schwartz's methodology } \\
\hline $\begin{array}{c}\text { Inner harmony } \\
\text { (be at peace with oneself) }\end{array}$ & 0,20 & $0,25^{*}$ & - & $-0,44 * *$ \\
\hline $\begin{array}{l}\text { Life full of impressions } \\
\text { (commitment to novelty) }\end{array}$ & 0,20 & $0,24 *$ & - & - \\
\hline National security & $0,26^{*}$ & - & - & - \\
\hline $\begin{array}{l}\text { Respect of other people's } \\
\text { opinion }\end{array}$ & - & $0,23^{*}$ & - & $-0,27 *$ \\
\hline $\begin{array}{l}\text { Respect for excepted } \\
\text { traditions, customs }\end{array}$ & - & $0,25 *$ & - & - \\
\hline
\end{tabular}

24 Леонтьев Д. А., Рассказова Е. И. Тест жизнестойкости. Москва : Смысл, 2006. 63 с.

25 Крюкова Т. Л., Куфтяк Е. В. Опросник способов совладания (адаптация методики WCQ). Журнал практического психолога. 2007. № 3. С. 93-112. 
Continued Table 3

\begin{tabular}{|c|c|c|c|c|}
\hline $\mathbf{1}$ & 2 & 3 & 4 & 5 \\
\hline Reserved in feelings and actions & - & - & $-0,31^{* *}$ & - \\
\hline $\begin{array}{l}\text { Open to other people's opinions, } \\
\text { ideas and beliefs }\end{array}$ & - & - & $-0,30^{* *}$ & - \\
\hline $\begin{array}{l}\text { Modest, simple, not seeking to be } \\
\text { attract notice }\end{array}$ & - & - & $-0,21$ & $-0,27 *$ \\
\hline Choosing own goals and intentions & $0,26^{*}$ & $0,30 * *$ & - & - \\
\hline Healthy physically or mentally & 0,20 & - & - & $-0,26^{*}$ \\
\hline $\begin{array}{l}\text { Accepting life (complying with life } \\
\text { circumstances) }\end{array}$ & - & - & $-0,35^{* *}$ & $-0,21$ \\
\hline $\begin{array}{l}\text { Preserving personal image } \\
\text { (protection of feeling of one's own } \\
\text { "face") }\end{array}$ & - & - & $-0,36^{* *}$ & - \\
\hline $\begin{array}{l}\text { Self-indulgent (tending to indulge } \\
\text { one's own desires) }\end{array}$ & $0,49 * * *$ & $0,36^{* *}$ & - & - \\
\hline \multicolumn{5}{|c|}{ Values - declared norms (Schwartz Value Survey) } \\
\hline Tradition & - & - & $-0,26^{*}$ & - \\
\hline Self-direction & $0,24^{*}$ & $0,31^{* *}$ & - & - \\
\hline Hedonism & $0,22 *$ & 0,19 & - & - \\
\hline Security & $0,25^{*}$ & $0,33^{* *}$ & - & $-0,32 * *$ \\
\hline \multicolumn{5}{|c|}{ Values - behavioral principles (Portrait Value Questionnaire) } \\
\hline Security & $0,26^{*}$ & $0,34 * *$ & - & - \\
\hline \multicolumn{5}{|c|}{ Laengle's Existence Scale } \\
\hline Self-distance & $-0,30 * *$ & $-0,19$ & - & 0,21 \\
\hline Self-transc & $-0,20$ & - & - & $0,23^{*}$ \\
\hline Responsil & $-0,26^{*}$ & - & - & $0,25^{*}$ \\
\hline Existential fulfillment & $-0,24 *$ & - & - & $0,26^{*}$ \\
\hline \multicolumn{5}{|c|}{ Korzhova's Questionnaire of Life Orientations } \\
\hline Life variability & $0,40 * * *$ & $\begin{array}{l}0,51^{* *} \\
*\end{array}$ & - & $-0,39 * * *$ \\
\hline Internal locus of control & - & - & $0,29 * *$ & - \\
\hline $\begin{array}{l}\text { Focus on the development of the } \\
\text { inner world }\end{array}$ & $0,48 * * *$ & $\begin{array}{c}0,41 * * \\
*\end{array}$ & - & $-0,51 * * *$ \\
\hline Life mobility & - & - & $0,44^{* * * *}$ & - \\
\hline $\begin{array}{c}\text { General indicator of subject-object } \\
\text { orientations }\end{array}$ & $0,31 * *$ & - & $0,03 * *$ & - \\
\hline \multicolumn{5}{|c|}{ Osin's Alienation Test } \\
\hline General alienation & - & - & - & $-0,22^{*}$ \\
\hline Alienation from work & - & - & - & $-0,21$ \\
\hline Alienation from society & - & - & - & $-0,23^{*}$ \\
\hline Alienation from & - & - & 0,19 & - \\
\hline Alienation from family & $0,38 * * *$ & $0,34 * *$ & - & $-0,19$ \\
\hline Alienation from self & - & - & - & $-0,20$ \\
\hline \multicolumn{5}{|c|}{ Maddi's Hardiness Personal Views Survey } \\
\hline Commitment & $-0,31 * *$ & $0.29 * *$ & - & $0,46 * * *$ \\
\hline Control & $-0,26^{*}$ & $-0,28^{*}$ & 0,18 & $0,33 * *$ \\
\hline Challenge & $-0,21$ & $-0,26^{*}$ & - & $0,30 * *$ \\
\hline General har & $-0,24^{*}$ & $-0,25^{*}$ & - & $0,39 * * *$ \\
\hline
\end{tabular}

Note. The table shows indicators whose absolute value is greater than 0,185 : * $\mathrm{p} \leq 0,05, * * \mathrm{p} \leq 0,01, * * * \mathrm{p} \leq 0,001$. 
Some important trends have been mentioned according to the data from table 3:

1. The recognition and rejection of a number of values are significantly associated with burnout symptoms - they can be their diagnostic markers, causes or consequences. In general, burnout is accompanied by the desire for inner harmony, an attitude to health and security as leading life principles, an increase in hedonistic attitudes, and the desire for novelty. We believe that such value orientations come as a result of a reassessment of life principles in the process of crisis development and are inherently protective and compensating. Orientation to the choice of one's own desires and goals may underlie burnout, since an active promotion of one's interests leads to "wasting oneself'.

Burnout is directly connected with the declared and valid value of "Security". The more emotionally exhausted a person is, the more important the security and stability of society, relationships, and himself/herself are. Self-preservation is the basis of this connection.

The value ideal "Self-Direction" (independence in thoughts and actions) is closely correlated with emotional exhaustion and the overall level of burnout. A similar relationship was also found with the Hedonism indicator, but the mechanism for the formation of these dependencies is most likely different. It is known that one of the consequences of burnout is self-indulgence, desire for comfort, for passive rest and sensual-material pleasures ${ }^{26}$.

2. The existential fulfillment of life directly correlates with the level of personal and professional accomplishments of educators and, obviously, is a factor opposing burnout. The expressiveness of burnout, on the contrary, correlates with manifestations of selfalienation and loss of meaning in different areas of life.

3 . The strongest and most global correlations relate to burnout and hardiness indicators. Professional effectiveness is accompanied by a high level of engagement, control over life circumstances and risk taking. Emotional exhaustion causes the reduction of all components of hardiness.

26 Левит Л. 3. Психология развития и реализации жизненного потенциала субъекта : дис. ... доктора психол. наук : 19.00.01. Киев, 2016. 605 с. 
4. None of the indicators of coping strategies showed significant correlations with burnout indicators.

5. The indicators of life orientations of the questionnaire of E. Yu. Korzhova demonstrate a complex structure of correlations with individual burnout symptoms. As a whole, subjective orientation turned out to be a factor provoking or enhancing burnout of specialists. As in the case of the "Self-Direction" value, this can be explained by the accelerated expenditure of vital resources - physical, emotional, motivational, cognitive, etc.

The facts obtained contradict the widespread opinion of subjectivity as the basis of personal growth and psychological wellbeing. An active life position is embraced in most cultures as the most socially acceptable type of behavior and way of thinking. But for the individual himself/herself, excessive commitment is dangerous with natural unhealthy consequences in the form of emotional exhaustion, disappointment, cynicism, negativity, and depreciation of his/her past goals and achievements.

To identify the internal structure of correlations of variables, we conducted a factor analysis (Extraction Method: Principal Component Analysis, without rotation). Five latent factors were identified in the result, together explaining $84 \%$ of the spread. As significant factor loads, we considered the coefficients of correlation of the indicator with the factor having an absolute value greater than 0.5 .

The first factor has its own value of 11.3 and determines $25.7 \%$ of the total variance. The main factor loadings belong to burnout components: emotional exhaustion and reduction of professionalism, as well as two indicators of subject-object orientations - vital variability (desire to change) and focus on the development of inner world (desire for self-enhancement). These indicators are accompanied by a decrease in hardiness due to the lack of commitment, instead of which a feeling of rejection and a sense of being "outside" the life come. The factor is called "Self-Enhancement Burnout". 
Table 4

Factor loads of the factor 1 "Self-Enhancement Burnout"

\begin{tabular}{|c|c|}
\hline Diagnosable factors & Correlation with factor \\
\hline Integral burnout rate & 0,920 \\
Emotional exhaustion & 0,887 \\
Professional accomplishment & $-0,866$ \\
Focus on the development of the inner world & 0,922 \\
Life variability & 0,889 \\
Commitment & $-0,864$ \\
General hardiness & $-0,855$ \\
Value orientation "Inner harmony" & 0,730 \\
Security (declared value) & 0,787 \\
Security (behavioral principle) & 0,605 \\
Self-distance & $-0,538$ \\
Self-transcendence & $-0,513$ \\
Responsibility & $-0,739$ \\
Existential fulfillment & $-0,599$ \\
General alienation & 0,538 \\
Alienation from family & 0,585 \\
Alienation from self & 0,515 \\
Professional experience & 0,720 \\
\hline
\end{tabular}

The factor positively correlates with professional experience (age), value orientation in achieving inner harmony (to be at peace with oneself), and the expressiveness of the basic value "Security". In this case, it is difficult to define whether burnout is the cause of life orientation to the changes, or on the contrary, an aspiration for selfenhancement is the cause of burnout.

The last version is quite acceptable taking into account the orientation toward internal and external perfection as a popular but not quite healthy trend that has overwhelmed a modern society. Unlike the ancient ideals of self-enhancement, modern perfectionist culture is based on a constant «self-promotion» and dissatisfaction with oneself. It should be noted that during the periods of historical and social crises, as a rule, the popularity of various spiritual practices grows. Society, bewildered and disappointed, is looking for new patterns of behavior, ways to support and strengthen themselves, often turning to various mystical and esoteric teachings. In any case, the identified 
factor requires more close study and explanation; this is the prospect of our further researches.

The factor negatively correlates with indicators of existential fulfillment (except for the Freedom scale), which indicates a concurrent crisis, a sense of emptiness and meaninglessness of life; this is confirmed by direct correlations with individual varieties of self-alienation: from family, from self. The latter can be interpreted as a substitute for the traditional symptom of depersonalization, which was not included in the factor. In this case, this is a common life cynicism and the loss of goals that were previously important to the individual.

The second factor has its own value of 10.8 and determines $24.6 \%$ of the total variance. Factor loads (Table 5) partially overlap with the content of factor 1, but have the opposite indicator: the rejection of the value of internal harmony and the absence of manifestations of selfalienation. The leading role here belongs to hedonism, "following one's own desires" as a declared value and a guiding principle of behavior. This is combined with an obvious desire for novelty (life mobility and the value of stimulation), the desire not to comply with traditions, generally accepted social norms and life circumstances. This is a kind of active life position in which the activity is aimed at the selfish provision of the individual's desires. Depersonalization logically fits into this trend as depersonalization of others, a negative and formal attitude towards people who make up the professional circle of communication. This is a modern type of consumerism "take everything from life".

The inclusion of the "Depersonalization" and "Alienation from work" indicators in factor 2 indicates that this type of life-realization is not an open and joyful interaction with the world, but narcissistic egoism, a consumer position. A person's own needs are higher than the requirements of society and the interests of other people, which are considered only as obstacles to free will. The factor positively correlates with the overall indicator of the coping behavior questionnaire, which indicates the stressful nature of this life strategy.

The factor is called "Hyperhedonism". Such a view of life is not something new and has been known since ancient times. Hedonistic ethics is rather useful, as it gives back the person a sense of the primordial value of being, harmony of soul and body. But uncontrolled 
hedonism, not balanced by a moral and ethical frameworks, is destructive for both man and society.

Table 5

Factor loads of the factor 2 "Hyperhedonism"

\begin{tabular}{|c|c|}
\hline Diagnosable factors & Correlation with factor \\
\hline Hedonism (behavioral principle) & 0,926 \\
Life mobility & 0,801 \\
Alienation from other people & $-0,878$ \\
Conformity (declared value) & $-0,735$ \\
Traditions (declared value) & $-0,723$ \\
Value orientation "Accepting life" & $-0,716$ \\
Value orientation "Self-indulgent" & 0,695 \\
General indicator of subjective alienation & $-0,687$ \\
Alienation from society & $-0,673$ \\
Hedonism (declared value) & 0,652 \\
Stimulation (behavioral principle) & 0,646 \\
General indicator of subject-object orientations & 0,645 \\
Alienation from self & $-0,636$ \\
General tension of coping strategies & 0,615 \\
Achievements (behavioral principle) & 0,587 \\
Traditions (behavioral principle) & $-0,585$ \\
Alienation from work & $-0,580$ \\
Depersonalization & 0,557 \\
Internal locus of control & 0,508 \\
\hline
\end{tabular}

The two factors described are the hidden basis of the observed relationship between burnout and life (value-semantic) orientation of the individual. According to the results obtained, it should be noted that A. Langle considers emotional burnout as a special form of existential vacuum - the result of the fact that a person does not experience the values in the profession for a long time, "performance of duty without worries",27.

On the other hand, it is known that burnout develops among the specialists who are most keen on their work - those who "have something to burn": "Excessive commitment to work, reliance on

27 Лэнгле, А. Эмоциональное выгорание с позиций экзистенциального анализа. Вопросы психологии. 2008. № 2. С. 3-16. 
professional activity as the main way of self-realization, limitation of other areas of life and interests, closure of internal meanings on any side of one's own life significantly increases the subjective price of mistake, failure, turning it into a personal catastrophe, affecting the entire value, semantic sphere, turning into existential problem of the loss of meaning" 28 . It happens that the individual's personal values do not correspond to the values and meanings of the activity in which he/she is engaged, or to the values of corporate culture (in this case, a particular educational institution).

The following factors do not directly relate to burnout, but present interesting options for life strategies that "free" a person from the risk of professional burnout.

The third factor (with its own value of $6.6 ; 15.5 \%$ of the total variance) reflects self-leadership as the main value vector that underlies the subjective activity and semantic fullness of life - see Table 6. The factor is called "Freedom of Thoughts and Action".

Table 6

Factor loads of the factor 3 "Freedom of Thoughts and Actions"

\begin{tabular}{|c|c|}
\hline Diagnosable factors & Correlation with factor \\
\hline Freedom & 0,791 \\
Value orientation «Choosing one's own goals» & 0,772 \\
Risk taking & 0,766 \\
Self-Direction (declared value) & 0,725 \\
Achievements (declared value) & 0,681 \\
Stimulation (declared value) & 0,643 \\
Benevolence(declared value) & $-0,615$ \\
Self-Direction (behavioral principle) & 0,573 \\
Existential fulfillment & 0,564 \\
Control & 0,555 \\
General hardiness & 0,540 \\
General indicator of subject-object orientations & 0,503 \\
Responsibility & 0,501 \\
\hline
\end{tabular}

${ }^{28}$ Бессонова Ю. В., Лазебная Е. О. Ценностные предпосылки выгорания субъекта труда. Выгорание и профессионализащия: сб. науч. трудов / под ред. В. В. Лукьянова и др. Курск : КГУ, 2013. С. 29-43. 
The existential freedom plays the main role here as the ability to choose one's own goals, make decisions on the basis of one's own values and find the corresponding opportunities of actions. Risk taking (both positive and negative components of the experience gained) provides overall hardiness. The declared value of independence is embodied in the real behavior. A feature of the value system is the distinctive orientation to the ideals of achievements, and stimulation and independence in the rejection of the prosocial orientation.

The fourth factor (with its own value of 4.6.; $10.5 \%$ of the total variance) arouses interest because it has a negative correlation with the indicator of depersonalization and alienation from work, that is, it can be considered as a force that counteracts the development of these negative symptoms. It represents the value ideal of universalism (understanding, tolerance, protection of the well-being of all mankind and nature) and embodied benevolence (maintaining the well-being of people with whom the individual is in direct contact). The humanistic and altruistic orientation, caring for others is a professionally important quality of teachers. This factor is called "Humanistic position".

Table 7

Factor loads of the factor 3 "Humanistic Position"

\begin{tabular}{|c|c|}
\hline Diagnosable factors & Correlation with factor \\
\hline Depersonalization & $-0,505$ \\
Universalism (declared value) & 0,684 \\
Benevolence & 0,632 \\
Universalism & 0,509 \\
Alienation from work & $-0,595$ \\
\hline
\end{tabular}

The fifth factor (with its own value of 3.3.; $7.5 \%$ of the total variance) is the opposite of those described in factor 3 . This is the rejection of self-leadership, an orientation towards supporting traditions and conformity in the social behavior. The basis of such behavior is a conscious rejection of self-dependence and selfdistance - a person's ability to move a distance in relation to himself/herself, to push back his/her desires, ideas and feelings. This 
provides group solidarity. This strategy, although somewhat contrary to the provisions of psychology of subjectivity, is nevertheless quite effective: it is oriented towards success and positively correlates with the general indicator of hardiness. The factor is called "Compliance with social expectations".

Table 8

Factor loads of the factor 5 "Compliance with social expectations"

\begin{tabular}{|c|c|}
\hline Diagnosable factors & Correlation with factor \\
\hline Achievements (declared value, ideal) & 0,581 \\
Traditions (current value) & 0,605 \\
Self-dependence (current value) & $-0,541$ \\
Conformity (current value) & 0,512 \\
Self-distance (SD) & 0,503 \\
\hline
\end{tabular}

Previously, when studying the value preconditions for professional burnout of rescuers of the Ministry of Emergencies, Yu. V. Bessonova and E.O. Lazebnaia (2013) came to the conclusion that the values of universalism and conformity are particular to specialists who are not subjected to post-traumatic stress; while with PTSD, people are guided not by universal values and inclusion in the world, but by their own needs. Well-adapted professionals do not separate themselves and society, considering themselves as successful members of it, included in the system of interaction with others. Our results confirm these findings and allow expanding them to different professional groups ${ }^{29}$. Our results confirm these findings and allow expanding them to different professional groups.

\section{CONCLUSIONS}

The analysis of the problem of professional burnout of a person revealed that this is a syndrome of physical, mental and emotional exhaustion. The result of this process is: negative self-esteem, a

${ }^{29}$ Бессонова Ю. В., Лазебная Е. О. Ценностные предпосылки выгорания субъекта труда. Выгорание и профессионализачия: сб. науч. трудов / под ред. В. В. Лукьянова и др. Курск : КГУ, 2013. С. 29-43. 
faceless attitude to professional activity, depersonalization. This is a crisis affecting the highest levels of psychological regulation, values and life meanings. At the same time, professional burnout of the personality is an individual process, which can be caused by the combinations of subjective and objective factors, which depend on life orientations, values, on ways of psychological protection and ways of alienation from social interaction.

As the results of psychological diagnostics have shown, professional burnout is not an indispensable attribute of the work of a teacher or the head of an educational institution. Exposure to this syndrome is closely associated with hardiness, with the characteristics of value-semantic sphere and life position.

The analysis of numerous correlations between the symptoms of burnout and characteristics of value-semantic sphere of educators actualizes the question of causes and consequences. As a result of the study, it was found that the value orientation determines a person's susceptibility to emotional exhaustion, cynicism and reduction of achievements, and also determines the expressiveness of these manifestations. Correlation connections made it possible to establish the opposite direction, value orientations are the result of negative professional experience, a kind of protective mechanism and a spontaneous attempt to self-preservation. Do certain values and meanings have a resource for overcoming the negative effects of burnout? The answer to this question will not be simple or direct.

Factor analysis revealed five general strategies for life-realization, which regulate the relationship between professional burnout and value-semantic orientations of educational principal staff and directorship: exhaustion by self-enhancement; hyperhedonism; freedom of thought and action; humanistic position; compliance with social expectations.

The results obtained open up wide opportunities for psychological assistance and prevention. We see an important prospect for further researches in conducting a longitudinal section of the symptoms of professional burnout of teachers (at the beginning and at the end of a school year, during periods of semester certification), monitoring 
psychological factors that provoke and slow down the development of burnout during the working cycle.

\section{SUMMARY}

The article discusses theoretical and empirical approaches to the study of professional burnout and changes in the personality's life position. An empirical study was carried out on a group of educational principle staff and directorship, as the sample with a traditionally leading position in the list of occupations exposed to risk of professional burnout.

It has been noted that professional burnout is a complex and important issue, which is based on a contradiction: on the one hand, an active and responsible life position is resource-consuming, i.e. contributes to burnout, on the other hand, finding the meaning and value of one's own activity is a condition for a long and successful existence in the profession.

It has been established that an active life position is embraced as the most socially acceptable type of behavior and way of thinking. However, for the individual himself/herself, excessive commitment is dangerous with natural unhealthy consequences in the form of emotional exhaustion, disappointment, cynicism, negativity, and the depreciation of his/her past goals and accomplishments.

The study conducted revealed five general strategies for liferealization, which regulate the relationships between professional burnout and value-semantic orientations of educational principal staff and directorship: exhaustion by self-enhancement; hyperhedonism; freedom of thought and action; humanistic position; compliance with social expectations.

\section{REFERENCES}

1. Бессонова Ю. В., Лазебная Е. О. Ценностные предпосылки выгорания субъекта труда. Выгорание и профессионализация: сб. науч. трудов / под ред. В. В. Лукьянова и др. Курск : КГУ, 2013. С. 29-43.

2. Бондарчук О. I. Соціально-психологічні основи особистісного розвитку керівників загальноосвітніх навчальних закладів у 
професійній діяльності : автореф. дис. ... д-ра психол. наук : 19.00.05. Київ, 2008. 34 с.

3. Водопьянова Н. Е., Старченкова Е. С., Наследов А. Д. Стандартизированный опросник «Профессиональное выгорание» для специалистов социономических профессий. Вестник СанктПетербургского университета. Серия 12. Социология. 2013. Вып. 4. С. 17-27.

4. Всемирная организация здравоохранения. Международная классификация болезней: «профессиональный синдром» эмоционального выгорания. URL: https:/www.who.int/ mental_health/evidence/burn-out/ru/ (дата звернення: 26.09.2019)

5. Демина Л. Д., Ральникова И. А. Психологическое здоровье и защитные механизмы личности. Барнаул: Изд-во АлтГУ, 2005. $132 \mathrm{c}$.

6. Карандашев В. Н. Методика Шварца для изучения ценностей личности: концепция и методическое руководство. Санкт-Петербург : Речь, 2004. 72 с.

7. Китаев-Смык Л. А. Организм и стресс. Стресс жизни и стресс смерти. Москва : Смысл, 2012. 464 с.

8. Коржова Е.Ю. Психология жизненных ориентаций человека. Санкт-Петербург : Изд-во РХГА, 2006. 384 с.

9. Кривцова С. В., Лэнгле А., Орглер К. Шкала экзистенции (Existenzskala) А. Лэнгле и К. Орглер. Экзистенцุиальный анализ. 2009. № 1. Бюллетень. С. 141-170.

10. Крюкова Т. Л., Куфтяк Е. В. Опросник способов совладания (адаптация методики WCQ). Журнал практического психолога. 2007. № 3. С. 93-112.

11. Левит Л. 3. Психология развития и реализации жизненного потенциала субъекта : дис. ... доктора психол. наук : 19.00.01. Киев, 2016. 605 с.

12. Лэнгле А. Эмоциональное выгорание с позиций экзистенциального анализа. Вопросы психологии. 2008. № 2. C. 3-16.

13. Осин Е. Н. Смыслоутрата как переживание отчуждения: структура и диагностика : дис. ... канд. психол. наук : 19.00.01. Москва. 2007. 217 с. 
14. Леонтьев Д. А., Рассказова Е. И. Тест жизнестойкости. Москва : Смысл, 2006. 63 с.

15. Bakker A. B., Demerouti E. Job demands-resources theory: Taking stock and looking forward. Journal of occupational health psychology. 2017. Vol. 22, № 3. P. 273-285. DOI:10.1037/ocp0000056.

16. Burish M. Das Burnout-Syndrom: Theorie der inneren Erschöpfung. Berlin, Heidelberg: Springer-Verlag, 2014. 292 p. DOI: 10.1007/978-3-642-36255-2.

17. Burnout is rising in the land of work-life balance [Video by M. Savage and B. Derrier]. BBC Worklife. URL: www.bbc.com/worklife/article/20190719-why-is-burnout-rising-inthe-land-of-work-life-balance (дата звернення: 03.09.2019)

18. Freudenberger H. Staff Burnout. Journal of Social Issues. 1974. Vol. 30. P. 159-165. DOI: 10.1111/j.1540-4560.1974.tb00706.x

19. Golembiewski R. T., Munzenrider R. Phases of burnout: Developments inconcepts and applications. New York: Praeger. 1988. $292 \mathrm{p}$.

20. Gunderman R. For the young doctor about to burn out. The Atlantic. 2014, February 21. URL: http://www.theatlantic.com/health/ archive/2014/02/for-th0e-young-doctor-about-to-burn-out/284005 (дата звернення: 26.09.2019).

21. Hubert S., Aujoulat I. Parental Burnout: When Exhausted Mothers Open Up. Frontiers in Psychology. 2018. Vol. 9. P. 1021. DOI: 10.3389/fpsyg.2018.01021.

22. Leitera M. P., Maslach C. Latent burnout profiles: A new approach to understanding theburnout experience. Burnout Research. 2016. Vol. 3. P. 89-100.

23. Maslach C., Jackson S. E. The measurement of experienced burnout. Journal of Occupational Behaviour. 1981. Vol. 2. P. 99-113.

24. Maslach C., Jackson S.E., Leiter M.P. Maslach burnout inventory. Manual (3rd ed.). Palo Alto, Calif. : Consulting Psychologists Press, 1996. 34 p.

25. Oosterholt B. G., Maes J. H., Van der Linden D., Verbraak M. J., Kompier M. A. Burnout and cortisol: Evidence for a lower cortisol awakening response in both clinical and nonclinical 
burnout. Journal of Psychosomatic Research. 2015. Vol. 78, Is. 5, P. 445-451. DOI:10.1016/j.jpsychores.2014.11.003

26. Savic I. Structural Changes of the Brain in Relation to Occupational Stress. Cerebral Cortex. 2015. Vol. 25, Is. 6. P. 1554-1564. DOI: 10.1093/cercor/bht348.

27. Schaufeli W. B. Opgebrand : over de achtergronden van werkstress : het burnout-syndroom. Rotterdam: Donker. 1990. 224 p.

28. Schaufeli W. B., Leiter M., Maslach C. Burnout: 35 Years of research and practice. Career Development International. 2009. Vol. 14, № 3. P. 204-220. DOI: 10.1108/13620430910966406

29. Toker S., Melamed S., Berliner S., Zeltser D., Shapira I. Burnout and risk of coronary heart disease: A prospective study of 8838 employees. Psychosomatic Medicine. 2012. Vol. 74 (8). P. 840-847. DOI:10.1097/PSY.0b013e31826c3174

\section{Information about the author:} Tavrovetska N.

Candidate of Psychological Sciences, Assistant Professor, Head of the Department of Practical Psychology, Kherson State University 27, University str., Kherson, 73000, Ukraine 